\title{
電子サイクロトロン共鳴加熱プラズマを用いた リニアスパッタリング装置の作動特性*
}

\author{
安井 利明*1. 松本 友宏*1. 田原 弘一 *1. 吉川 孝雄*1
}

（受理1998年12月 1 日，揭載決定1999年 2 月 6 日）

\author{
Operational Characteristics of Linear Sputtering Source \\ Using Electron Cyclotron Resonance Plasma \\ Toshiaki YASUI*1, Tomohiro MATSUMOTO*1, \\ Hirokazu TAHARA*1 and Takao YOSHIKAWA*1 \\ *1 (Graduate School of Engineering Science, Osaka University \\ Machikaneyama 1-3, Toyonaka, 560-8531, Osaka)
}

(Received December 1, 1998, Accepted February 6, 1999)

\begin{abstract}
A linear sputtering source using electron cyclotron resonance (ECR) plasma was developed for reactive sputter deposition with large area. It is composed of slot antennas on a rectangular waveguide with $268 \mathrm{~mm}$ long, permanent magnets around the slots and a target within the discharge chamber. Microwaves of $2.45 \mathrm{GHz}$ are radiated from the slots and generated plasma along the waveguide. A sputtering target is placed within the discharge chamber to achieve high deposition rate. Moreover, this plasma source prevents microwave window contamination by sputtered particles. The spatial uniformity of Ar plasma at $0.146 \mathrm{~Pa}$ was $\pm 7.8 \%$ within $180 \mathrm{~mm}$ in the long direction. By using Ti target and mixture of $\mathrm{Ar}$ and $\mathrm{N}_{2}$ gases, TiN films were successfully deposited with thickness uniformity of $\pm 11.3 \%$ within $160 \mathrm{~mm}$ and deposition rate of $16.2 \mathrm{~nm} / \mathrm{min}$.
\end{abstract}

\section{1.はじめに}

将来の大面積プラズマプロセスを可能にする一つの方 法として, 細長いシート状プラズマを用い, 流れ工程で 等価的に大面積処理を行ら方法が考えられている.この シート状プラズマの生成にマイクロ波を用いたプラズマ 源はその簡素な構造にもかかわらず，クリーンかつ高密 度プラズマを一様に生成できることから注目を集めてい る1-7). 特に磁場を併用した電子サイクロトロン共鳴加 熱（ECR）を用いたシート状プラズマ源 ${ }^{3-7)}$ は, 低圧下 での放電が可能なため, スパッタ源・イオン源のソース プラズマとしての応用も期待できる. 本研究室では, こ れまで方形導波管上に切ったスロットアンテナと永久磁

* 平成 10 年 11 月 12 日 第 39 回真空に関する連合講演会で講演

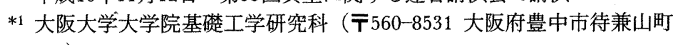
$1-3$ )
石を用いたシート状 ECR プラズマ源の開発を行い, そ のプロセス応用としてスパッタ成膜実験を行ってき た5-7). シート状 ECR プラズマ源をスパッタリング成膜 に用いる場合，マイク口波投入空へのスパッタ蒸着を低 減するために，ターゲットを放電室出口にプラズマ流と 平行に配置する必要があった。このため, プラズマ密度 の低下を避けられず成膜速度を高めることができない 上, マイクロ波投入空へのスパッタ蒸着を完全に防ぐこ とはできなかった.

そこで, 成膜速度を高めるために放電室内部にターゲ ットを配置し, さらにマイク口波投入空へのスパッタ蒸 着を防ぐためにターゲットの死角となる後方よりマイク 口波の入射が可能な構造を持つリニアスパッタリング装 置を新たに考案した. 本報告では, 本装置の作動特性と して放電室内で生成されるプラズマの特性と反応性スパ ッタリングによる窒化チタン薄膜の成膜特性を調べた結 


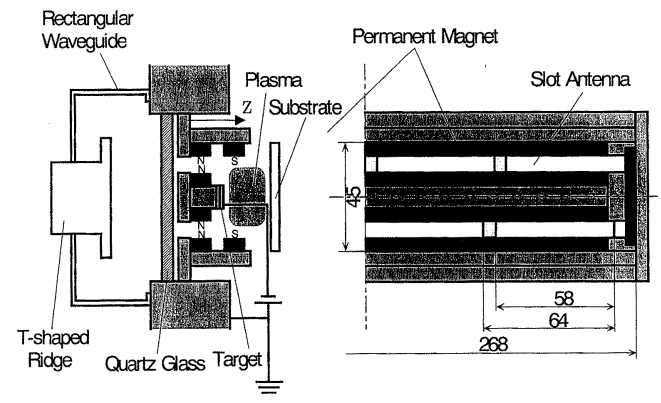

Fig. 1 Linear sputtering source using electron cyclotron resonance plasma.

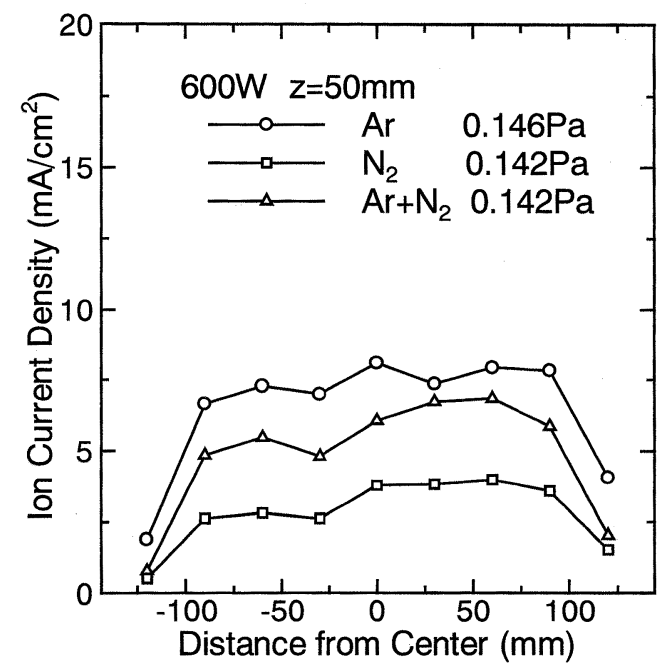

Fig. 2 Spatial profile of plasma along the linear sputtering source. ( $50 \mathrm{~mm}$ downstream from slot antenna.)

果について報告する.

\section{2. 実験装置}

Fig. 1 とシート状 ECR プラズマを用いたりニアスパ ッタリング装置を示寸. 方形導波管の側面にマイクロ波 投入空とスロットアンテナ板が設置されている. 導波管 の管軸方向に沿って 2 本のスロットがスロットアンテナ 板に切られて杼り，このスロットを通じてマイクロ波を 放電室（W268 $\times \mathrm{H} 21 \times \mathrm{D} 19 \mathrm{~mm} ）$ に入射する.ターゲ ット $(\mathrm{L} 240 \times \mathrm{W} 10 \mathrm{~mm})$ は, 2 本のスロットの間に下流 に向けて設置される. 各スロット周りを永久磁石列で囲 みターダット近傍に $875 \mathrm{G}$ の ECR 面を生成し, ターゲ ット近傍での高密度プラズマの生成を可能にする. 基板 はターゲット表面から $35 \mathrm{~mm}$ 下流の放電室出口に正対 させて配置する.ターゲットは, 放電室壁面からセラミ ック板により絶縁支持されて拉り, 放電室壁面に対しタ

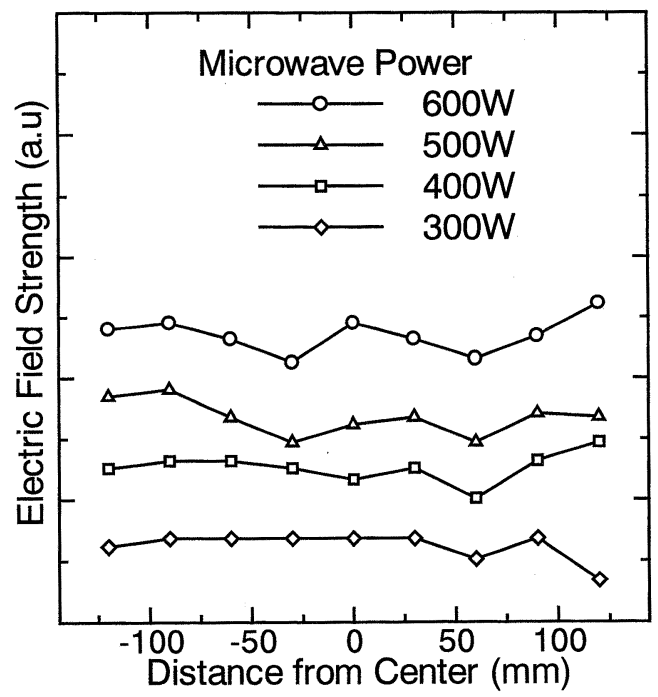

Fig. 3 Electric field distribution along the linear sputtering source.

ーゲット材にのみスパッタ電圧を加えることができる. 基板は放電室壁面と共に接地されており，加熱などは行 わない，磁石の固定されているスロットアンテナ板を水 冷する事により磁石の温度上昇を抑制しているが，磁石 表面の局所加熱を避けるため主に $600 \mathrm{~W}$ 以下のマイク口 波入力で実験を行った．本装置では，ターゲット位置か らスロット後方のマイクロ波投入空は死角となるため, 空へのスパッタ蒸着を防ぐことができる. 更にターゲッ トと基板を正対して配置する事により，高い成膜速度と プラズマ流による基板表面での反応促進が期待される.

得られた膜はX 線光電子分光法 (XPS) を用いて分析 した.

\section{3. 実験結果と考察}

\section{1 プラズマの特性}

静電単探針により測定した飽和イオン電流密度の放電 室長軸方向の空間分布を Fig. 2 亿示す. 作動ガス Ar, 放電室圧力 $0.146 \mathrm{~Pa}$ の時, $180 \mathrm{~mm}$ の範囲でプラズマの 空間変動は土7.8\%以下であった，この時，中央でのプ ラズマ密度は $1.04 \times 10^{17} \mathrm{~m}^{-3}$ と高い值が得られている. しかし, 作動ガス $\mathrm{N}_{2}$, 放電室圧力 $0.142 \mathrm{~Pa}$ の時, 空間 変動は90 mm の範囲で $19.1 \%$ ときくなり，そのプラ ズマ密度も $7.87 \times 10^{16} \mathrm{~m}^{-3}$ と低かった. Fig. 3 にスロッ トアンテナから放射されるマイク口波電場の $\mathrm{z}$ 方向成分 の空間分布をプラズマ負荷のない状態で測定した結果を 示す. Fig. 2 との比較から電場のピークの位置にプラズ マが強く生成されていることが分かる、作動ガスに混合 ガス $\left(\mathrm{N}_{2} / \mathrm{Ar}=1\right)$, 放電室圧力 $0.142 \mathrm{~Pa}$ の時, 飽和イオ 
Table 1 Sputtering condition.

\begin{tabular}{l|c}
\hline \hline Target & $\mathrm{Ti}$ \\
Working gas & $\mathrm{N}_{2} / \mathrm{Ar}=0.5 \sim 2.0$ \\
Pressure & $0.132 \sim 0.141 \mathrm{~Pa}$ \\
Microwave power & $600 \sim 700 \mathrm{~W}$ \\
Target bias voltage & $200 \mathrm{~V}$ \\
Substrate & glass \\
\hline
\end{tabular}

ン電流密度は $\mathrm{Ar}$ と $\mathrm{N}_{2}$ のほぼ平均的な值をとるが，そ の空間分布は $\mathrm{N}_{2}$ の場合を強く反映した分布となった.

作動ガス $\mathrm{Ar}$, 放電室圧力 $0.146 \mathrm{~Pa}$ で, ターゲット電 圧に対するターゲット電流の変化を調べた。ターゲット 電流は $200 \mathrm{~V}$ 前後で最大值をとり, 更に電圧を加えると 緩やかに減少する傾向が見られた，マイクロ波電力 600 $\mathrm{W}$ の時, ターゲット電压 $200 \mathrm{~V}$ で $82 \mathrm{~mA}\left(3.21 \mathrm{~mA} / \mathrm{cm}^{2}\right)$ の最大のターゲット電流が得られた. そこで, このター ゲット電圧 $200 \mathrm{~V}$ で成膜実験を行った.

\subsection{2 成膜特性}

ターゲットに $\mathrm{Ti}$, 作動ガスに $\mathrm{Ar}$ と $\mathrm{N}_{2}$ の混合ガスを 用いて反応性スパッタリングによる窒化チタンの成膜実 験を行った，成膜条件を Table 1 飞示す． 5 時間の成膜 の間, 基板ホルダー中央部での基板温度はどの成膜条件

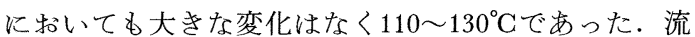
量比 $\mathrm{N}_{2} / \mathrm{Ar}$ の増加と共に成膜速度は低下するが， $\mathrm{N}_{2} /$ $\mathrm{Ar}=1.5$ の時に最も高い原子組成比 $\mathrm{N} / \mathrm{Ti}=0.48$ が得られ た.この時, 成膜速度は $14.0 \mathrm{~nm} / \mathrm{min}$ であった. ターゲ ットを放電室出口に設置した場合も, 流量比の変化に対

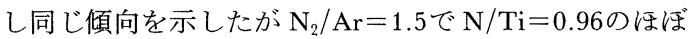
理論組成比に一致する膜が得られていた。しかし，この 時の成膜速度は7.5 nm/min と低かった ${ }^{5,6)}$.

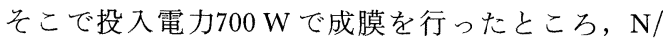
$\mathrm{Ti}=1.1$ とほぼ理論組成比に一致する膜が得られた。 た，XPSスペクトルの波形解析からもはっきりとした $\mathrm{Ti}-\mathrm{N}$ 結合の存在が確認できた．本装置ではターゲット を放電室内部に設置した結果, ターゲットを放電室出口 に設置した場合と比較してスパッタによる Ti の基板へ

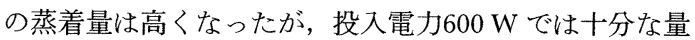
の活性な N ラジカルを基板表面に供給できていなかっ たと推測される。

投入電力 $600 \mathrm{~W}, \mathrm{~N}_{2} / \mathrm{Ar}=1.5$ で得られた膜厚及び原子 組成比の空間分布を Fig. 4 亿示す. $160 \mathrm{~mm}$ の範囲で $\pm 11.4 \%$ の一様性をもつ膜厚分布が得られた. しかし， 膜の原子組成比 $\mathrm{N} / \mathrm{Ti}$ の空間分布には強い不均一性が現 れた。これはFig. 2 に示した窒素プラズマの空間的な

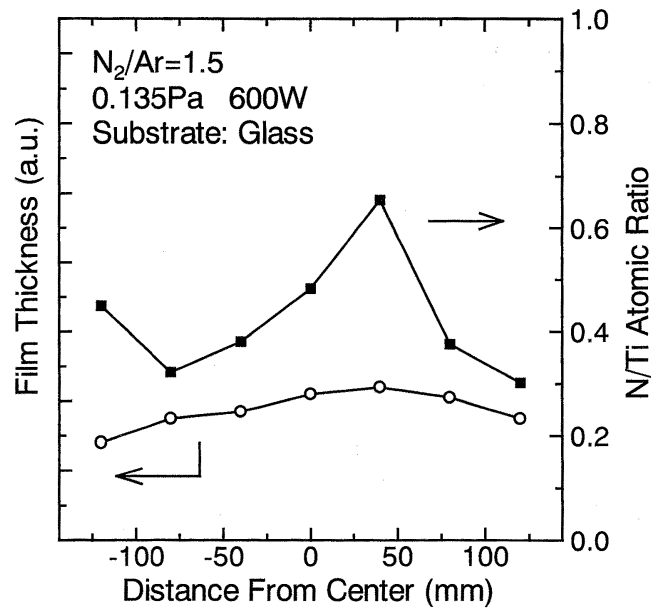

Fig. 4 Spatial distribution of deposited film thickness and atomic composition ratio along the linear sputtering source.

不均一が強く影響していると考兄られる. 基板の各位置 でのスパッタされた Ti と活性な N ラジカルの輸送比が 異なっていることが主な原因と考えられる.

\section{4. 結 論}

本研究ではターゲットを放電室内に設置する事により 成膜速度を高め，更にマイクロ波投入空へのスパッタ蒸 着を防ぐことができるリニアスパッタリング装置を新た に開発し，その作動特性を明らかにした。本装置では, $\mathrm{Ar}(0.146 \mathrm{~Pa})$ で空間分布が $180 \mathrm{~mm}$ の範囲で $\pm 7.8 \%$ 以 内の一様性を持つプラズマが生成できた。 また，反応性 スパッタリングにより $\mathrm{TiN}$ 膜を $160 \mathrm{~mm}$ の範囲で $\pm 11.3 \%$ 以内の一様性で成膜し，その成膜速度を 14.0 $\mathrm{nm} / \mathrm{min}$ と高めることができた。

\section{〔文献〕}

1) K. Komachi: J. Vac. Sci. Technol., A12 (1994) 769.

2) T. Tahara, J. Kitayama, T. Yausi, K. Onoe and Y. Tsubakishita and T. Yoshikawa: Rev. Sci. Instrum., 65 (1994) 669

3) A. Ishii, S. Amadatsu, S. Minomo, M. Taniguchi and M. Sugiyo: J. Vac. Sci. Technol., A12 (1994) 1068.

4) 吉木宏之: 真空, 41 (1998) 802.

5) T. Yasui, K. Nakase, H. Tahara and T. Yoshikawa: Jpn. J. Appl. Phys., 35 (1996) 5495.

6) 安井利明, 西土井健, 中瀬清隆, 田原弘一, 吉川孝 雄 : 真空, 40 (1997) 224.

7) T. Yasui, T. Nishidoi, H. Tahara and T. Yoshikawa: Proc. 13th Int. Symp. Plasma Chemistry, Beijing (1997) 444 